\title{
Sciendo
}

DOI: $10.2478 /$ lpts-2019-0034

\section{PARAFFIN PERMEABILITY OF SYNTHETIC GYPSUM BINDERS MODIFIED BY INDIVIDUAL POLYMERS}

\author{
K. Powała, D. Heim \\ Department of Environmental Engineering \\ Lodz University of Technology \\ ul. Wólczańska 213, 90-924 Łódź, POLAND \\ E-mail: dariusz.heim@p.lodz.pl
}

\begin{abstract}
The paper presents an experimental study of five different gypsum composites taking into account paraffin permeability. The composites consist of synthetic gypsum, paraffin and polymers. The samples were produced from gypsum slurry of mixing ingredients, all in the liquid state. After 7 days of maturing, the condition of the samples was assessed as well as drying time was determined. In the second part, the paraffin tightness of different samples was analysed. The results showed that after three weeks of tests the tightness sample was A4. Other polymers were characterised by lower tightness. The content of polymer had also the effect on the final results, but the direct relation between polymer content and paraffin tightness was not observed.
\end{abstract} tightness

Keywords: admixture, gypsum, polymer, phase change materials,

\section{INTRODUCTION}

The synthetic gypsum products are commonly used in the building industry [1]. The production of gypsum lies in the conversion of calcium carbonate in flue gas desulfurization technology using a wet limestone method that is often integrated with coal combustion in power plants [2]. Some power production in a European country, like Poland or Germany, is still based on coal burning. Therefore, in such cases the direct production of gypsum elements on site (in the factory located nearby) is possible. Even the gypsum application in the construction sector is widely known for 5000 years [3], the contemporary products are often modified to achieve better thermophysical properties. There are two main chemical compounds, which have been widely investigated and tested over recent decades: water-soluble polymers and phase change materials.

The main goal of using polymers in gypsum slurry is the modification of setting process, which involves gypsum hydration/crystallization and final structure 
of gypsum matrix [4]. Based on the application in cements, Pouches revealed that polymers had the considerable influence on hydration delay [5]. Bülichen [6] and Patural [7] showed that HEMC improved water retention of cement and gypsum. Moreover, the influence of Tylose MH1000 content on gypsum thermal conductivity was also confirmed [8]. On the other hand, to increase the durability of cementitious composites, various internal curing agents, including superabsorbent polymers (SAPs), are often used [9]. In gypsum polymers, the porosity, pore-structure, water retention and mechanical properties change considerably [10]. The effect of microstructure on moisture diffusivity in cement mortars was determined by Garbalińska et al. [11], [12].

The incorporation of different types of phase change materials in gypsum plaster or wallboard leads to a considerable increase in their thermal inertia [13]. The first investigated technology based on the direct application of fatty acids in gypsum slurry [14], [15] or paraffin [16], [17] suffers from the leakage problems [18]. Newly emerging materials containing phase-change materials are based on micro-encapsulation of paraffin. The idea of this solution is the placement of paraffin in a special capsule, small spheres that keep the material in the stable form under all conditions [19], [20], [21]. Such acrylic microcapsules can be directly incorporated into a gypsum product. However, the total volume of pure PCM closed inside the capsules is relatively low in comparison with the total volume. Moreover, this solution is very expensive to use due to the production cost of microcapsules, which disqualifies large-scale use of phase-change material.

The main goal of the present study is to improve the existing technology by increasing the tightness using a polymer. In the experimental analysis, the paraffin was used as a phase change material, mixed with gypsum slurry modified by five types of polymers. The commercially available paraffin, RT25, was widely used in past for building product application: opaque - [22] or transparent [23]. The main advantages of paraffin are primarily the large heat capacity so that it allows accumulating heat. However, it should be mentioned that the use of paraffin has, unfortunately, many negative effects on buildings. One and the most dangerous is its flammability. Another disadvantage is undoubtedly the reduction of the strength of the final product. Some research was devoted to the application of fibre and plasticizer [24]. The last disadvantage from the perspective of paraffin application in building layers is low thermal conductivity, which is of great importance in the case of heat transfer [25].

The objective of the present research is to determine which polymer gives the best results in terms of permeability of paraffin through a gypsum composite. This is extremely important in the case of the application of a layer, in which paraffin is contained. The leakage of paraffin when it is in a liquid state is unacceptable. Another quite important feature of such an application is the avoidance of a very expensive process which is micro-encapsulation. The process consists in closing the phasechange material in small capsules, which means that there is no leakage outside. The idea behind the research is to check whether the use of selected polymers in a mixture of gypsum and paraffin will bring tangible results of maintaining the paraffin inside the mixture. 


\section{MATERIAL SELECTION}

The materials used in this study are four polymers from group A and one polymer from group B, in different proportions. The group A is characterised by the use as a binder in deeply penetrating and universal soils for various substrates, e.g., made of concrete, bricks, plasterboard, gypsum plaster, while the group B creates a different structure on the paint surface, resulting in superior durability and performance. The emulsion is built from an organic, pure acrylic polymer and an inorganic SiO2-phase. The used paraffin was RT25 produced by Rubitherm. RT25 is characterised by a melting point between $16-31^{\circ} \mathrm{C}$, with a peak latent heat at $25^{\circ} \mathrm{C}$. Total heat storage capacity is $210 \mathrm{~kJ} / \mathrm{kg}$. Heat conductivity is $0.2 \mathrm{~W} /(\mathrm{m} \cdot \mathrm{K})$. The gypsum used for the sample preparation was produced using the wet limestone method in the brown coal power plant. More information about the used polymers is listed below and compared in Table 1.

A1 - Polymer used mainly as a binder for the production of decorative and protective external coatings resistant to changing weather conditions. It is a polymer used in universal soils. $\mathrm{pH}$ 8.0-8.5. Dry matter content $50 \pm 1 \%$.

A2 - Vinyl-male copolymer, a binder in internal paints, in masses and decorative plasters. $\mathrm{pH} 3.5-5$. Content of dry substance $50 \pm 2 \%$.

A3 - Polymer with high flexibility and adhesion to the substrate. pH 4.0-6.0. Dry substance content $49 \pm 1 \%$.

A4 - Designed for forming protective and decorative coatings for mineral surfaces, especially for mosaic plasters.

B1 - Polymer used in paints due to its construction and composition based on pure acrylic polymer allows for the creation of a nanocoating, which is characterised by high fire resistance.

Table 1

Types and Properties of Polymers Used in the Experiment

\begin{tabular}{|l|c|c|c|c|c|}
\hline & $\mathrm{A} 1$ & $\mathrm{~A} 2$ & $\mathrm{~A} 3$ & $\mathrm{~A} 4$ & $\mathrm{~B} 1$ \\
\hline Application & $\begin{array}{c}\text { Universal } \\
\text { cover }\end{array}$ & $\begin{array}{c}\text { Inks in the } \\
\text { interior }\end{array}$ & $\begin{array}{c}\text { Binder for the } \\
\text { substrate }\end{array}$ & $\begin{array}{c}\text { Impregnate for } \\
\text { brick and stone }\end{array}$ & Emulsion \\
\hline $\mathrm{pH}$ & $8.0-8.5$ & $3.5 \div 5.0$ & $4.0 \div 6.0$ & $7.5 \div 8.5$ & No data \\
\hline $\begin{array}{l}\text { Dry content } \\
\text { substance }[\%]\end{array}$ & $50 \pm 1$ & $50 \pm 2$ & $49 \pm 1$ & $50 \pm 1$ & 45 \\
\hline $\mathrm{MTTF}^{*}\left[{ }^{\circ} \mathrm{C}\right]$ & $8 \div 12$ & $4 \div 6$ & 0 & $13 \div 19$ & 7 \\
\hline $\mathrm{T}_{\mathrm{g}}^{* *}\left[{ }^{\circ} \mathrm{C}\right]$ & $18 \div 22$ & $18 \div 20$ & $-2 \div 0$ & 22 & 12 \\
\hline
\end{tabular}

* - minimum film forming temperature $\quad * *$ - glass transition temperature

\section{SAMPLE PREPARATION}

In the presented study, the samples were prepared using silicone molds and containers with a capacity of $100 \mathrm{ml}$. The order in which the components were introduced was as follows. In the beginning, the plaster was weighed and added first to the container. The appropriate amount of water was then measured and mixed 
until suitable consistency was obtained. Then a measured amount of paraffin was introduced and the polymer was added and everything was mixed for about 15 seconds. The order concerned both silicone molds and containers, with the right proportions for each option. At the initial phase of testing, it was checked whether it was possible to mix the polymer together with gypsum and paraffin. Suitable silicone molds were used that allowed making samples with a mass of $500 \mathrm{~g}$. Based on the literature review, it was found that the most effective ratio of paraffin to gypsum was $0.2: 1$. Samples were made for each polymer with different percentages: $0.5 \%$, $1.0 \%, 2.0 \%, 3.0 \%, 5.0 \%$ and $10.0 \%$. Subsequently, samples of the mixture of gypsum and polymer were made in the same polymer content excluding samples of $5.0 \%$ and $10.0 \%$. The paraffin was then poured onto the surface of the dried material.

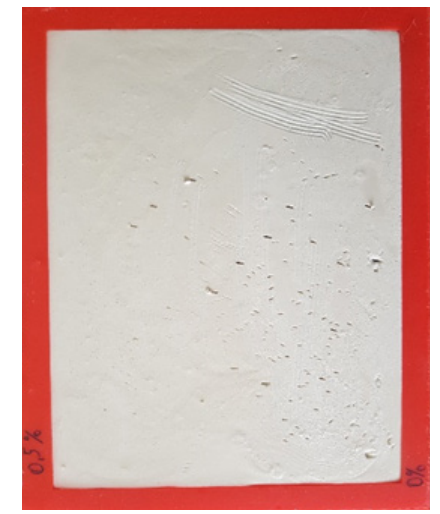

Fig. 1. Gypsum product sample (500 g) in silicon form to determine the mixing possibilities of gypsum, polymer and paraffin.

\section{INITIAL RESULTS - MATURING OF COMPOSITES}

In the present study, the drying time was determined on the basis of organoleptic sensations. As a result of drying the material, an indicator was introduced, which after pressing the mixture showed whether the material had already dried or not. Examination of the possibility of mixing the polymer together with paraffin and gypsum took two weeks during which $500 \mathrm{~g}$ samples were made and then the drying process was observed. In some samples, especially with contents of $5 \%$ and $10 \%$, the polymer leaked onto the gypsum surface. In another case, using the polymer A3, after the mixture dried, it shrank and then broke down, which directly eliminated this polymer from further tests.

On the basis of the conducted research, the drying time for individual polymers was evaluated in several ranges. As can be seen in each case, the increase in the proportion of polymers also increased the drying time. For the A3 polymer, it was not possible to determine the drying time unambiguously, so no graph showing the drying process was made. The graphs presented in Fig. 4 show the drying time depending on the proportion of polymer. 
a)

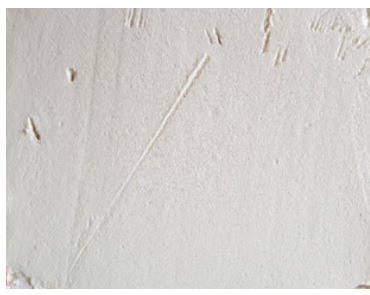

b)

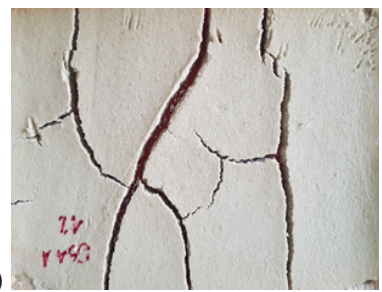

Fig. 2. Gypsum plaster with $1 \%$ of polymer (A3) and paraffin, a) before drying, b) after weekly drying.

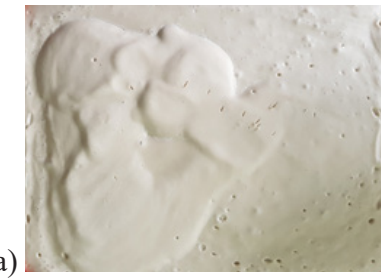

Fig. 3. The best sample with the A4 polymer a) before drying b) after drying.

b)
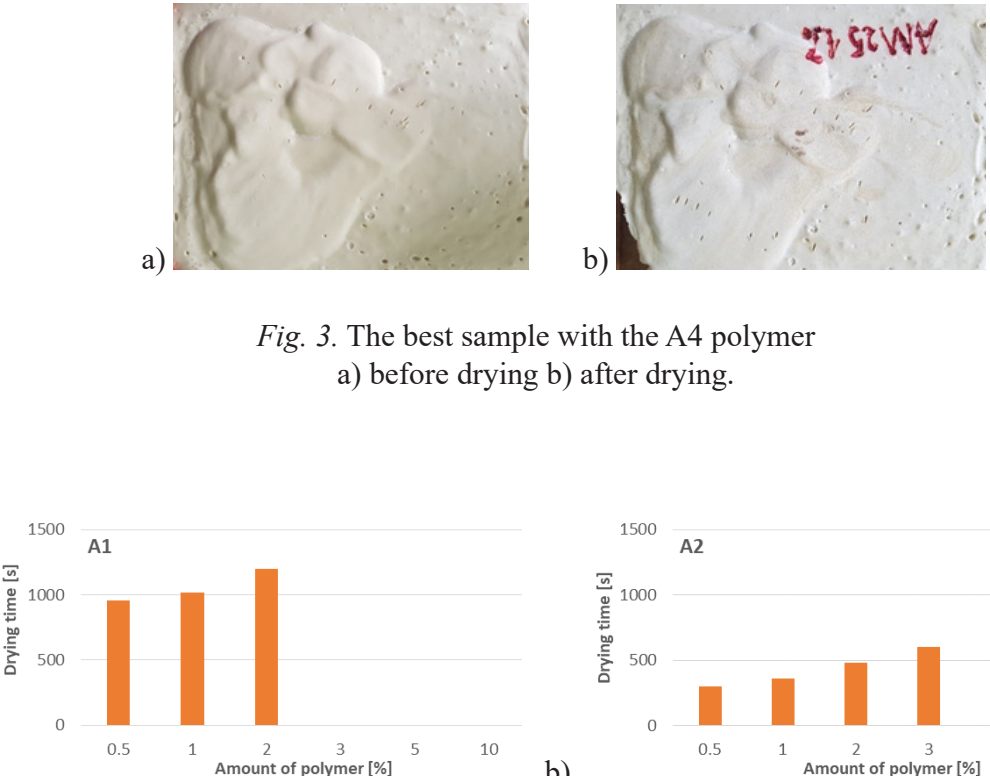

b)
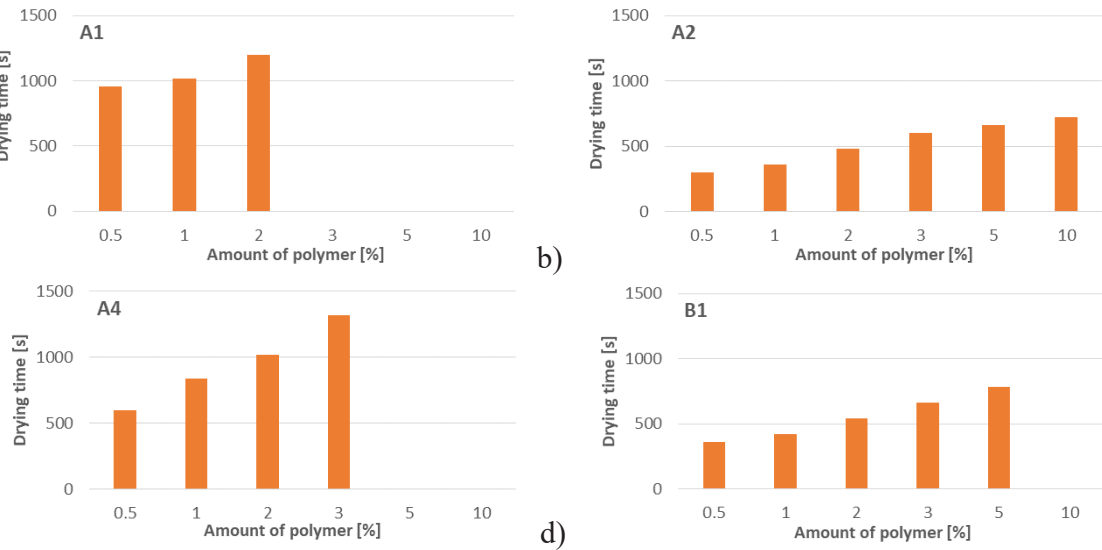

d)

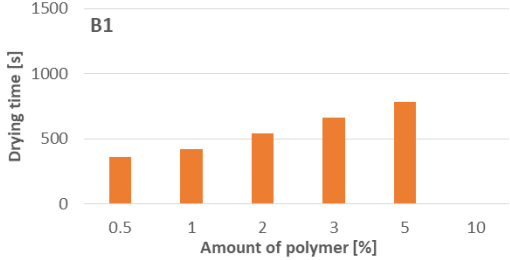

Fig. 4. Drying time for gypsum slurry with paraffin and different polymer mixtures a) A1, b) A2, c) A4, d) B1.

Analysing the graphs in Fig. 4, it can be concluded that the best polymers in terms of drying time are $\mathrm{A} 2$ and $\mathrm{B} 1$. In both cases, the lowest proportion of polymer gave a result of about 360 seconds, and the highest value, i.e., $10 \%$, did not exceed 720 seconds. Unfortunately, in both cases, the drying speed was the only advantage of application in the building layer because, as it was shown in paragraph 5, both polymers did not keep the paraffin inside in the period of three weeks. 


\section{PARAFFIN PERMEABILITY}

Another test to determine the suitability of the mixture for use as a building layer was to prepare samples in $100 \mathrm{ml}$ cylinder vessels with a diameter of $57 \mathrm{~mm}$, after which the mixture was allowed to dry for a week. To carry out this test, the cups were specially prepared by making several holes on the bottom. At the beginning of the test, the holes were sealed and the gypsum slurry was produced according to the receipt provided in Section 3. The next step was to expose the holes made at the bottom of the samples. Then paraffin was poured onto the top of the sample so that the paraffin could pass through the samples and flow out through the exposed holes. Thanks to this step, it was easy to check whether a given polymer improved the paraffin tightness. In each case, the same amount of gypsum and polymer mixture was applied to each cylinder cup equal on the high of $20 \mathrm{~mm}$. Each sample contained the same volume of paraffin equal to $1140 \mathrm{~mm}^{3}$. Due to the fact that each polymer interacts differently with gypsum, a various value was obtained in the drying process.

Table 2

The Amount of Gypsum Mixture with the Polymer after a Week of Drying

\begin{tabular}{|l|c|c|c|c|}
\hline \multirow{2}{*}{ Polymer type } & \multicolumn{4}{|c|}{ Content of polymer, \% } \\
\cline { 2 - 5 } & 0.5 & 1.0 & 2.0 & 3.0 \\
\hline A1 & 12 & 15 & 15 & 15 \\
\hline A2 & 23 & 23 & 20 & 15 \\
\hline A3 & 18 & 17 & 15 & 17 \\
\hline A4 & 17 & 15 & 12 & 11 \\
\hline B1 & 20 & 22 & 22 & 22 \\
\hline
\end{tabular}

Analysing the results presented in Table 2, it can be seen that the proportion of polymer in each case gave different results. Polymers such as A1 and A4 reduced the amount of the mixture compared to the sample before drying. On the other hand, the polymer A2 showed that the mixture increased in volume compared to the initial state. The situation was similar for the polymer B1.

As mentioned before, the samples were left for a week to mature and dry properly. Thanks to this form of the mixture, paraffin was poured in for further testing. In each sample, it was introduced in the same amount of paraffin $(20 \mathrm{~mm}$ of liquids on the gypsum). The paraffin level was checked at intervals of 7 days after pouring paraffin on the surface of the gypsum in the containers.

Analysing Fig. 5, it can be seen that the smallest loss of paraffin was noted by the A4 polymer, which in a 3-week interval lost only $2 \mathrm{~mm}$ in the case of a $0.5 \%$ share and the same in the share of $2.0 \%$. The largest changes in the amount of paraffin were recorded in both $2.0 \%$ and $3.0 \%$. The major changes were noted for polymer A3, in which each share after 3 weeks allowed for a total loss of paraffin. 
a)
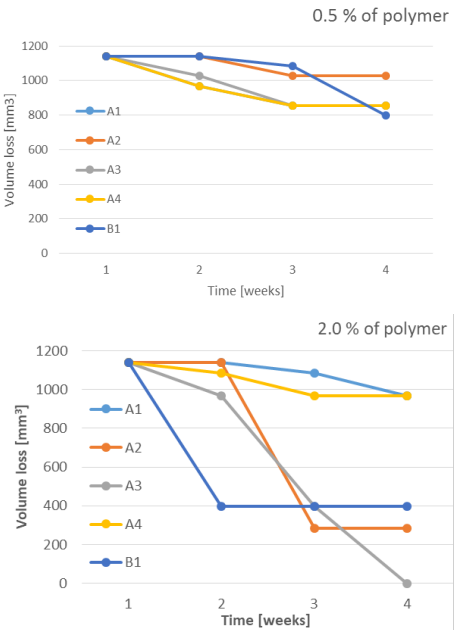

b)

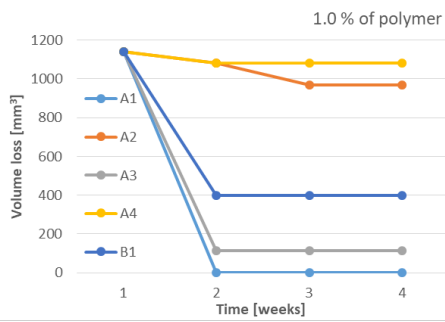

d)

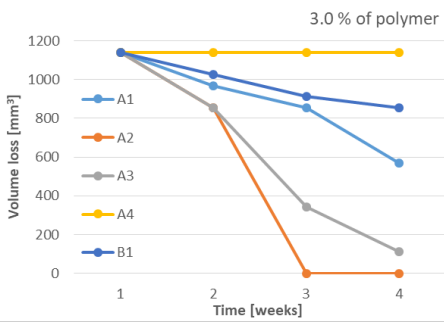

Fig. 5. Paraffin permeability after 3 weeks from the time it was applied to the surface of a sample of gypsum and polymer a) with a $0.5 \%$ share, b) with a $1.0 \%$ share, c) with a $2.0 \%$ share, d) with a $3.0 \%$ share.

As mentioned before, the samples with $5.0 \%$ and $10.0 \%$ share were not taken into account because in each of the samples the results did not give satisfactory outcomes. This was mainly due to the fact that the polymer content was too high, which did not combine with the mixture of gypsum and paraffin, and a large part of it was not inbuilt but remained on the surface of the sample until it evaporated.

\section{CONCLUSIONS}

As a result of research on a mixture of plaster, paraffin and polymers, several conclusions can be drawn. First of all, it has been confirmed that the polymer has an unequivocal effect on the properties of gypsum product. In one case, it causes excess gypsum foaming, but in the other case polymer does not combine with the mixture in $100 \%$. Another relatively important feature that has been revealed during the addition of the polymer is the extension of the drying time of the mixture. However, the most important feature that reveals during the addition of the polymer is the decrease in the strength of gypsum. The structure of the mixture in several samples led to gypsum cracking already after drying, and most of the samples were damaged during demoulding.

Analysing the second part of the research, some additional conclusions can be drawn. Based on the tests carried out, it can be observed that the volume of gypsum contained a different proportion of polymers. At the same volume in each sample, after a week of drying, it turned out that in some samples the volume exceeded the initial state. Therefore, based on the results of leakage experiments the best polymer that was used in this study was A4. Choosing the A4 polymer was mainly guided by the smallest losses resulting from the passage of paraffin through the structure. Therefore, the A4 polymer gave the best results in terms of paraffin permeability. It can be seen that, when compared to the second permeability of the B1 polymer, 
the fluctuations were definitely greater, especially at $1 \%$ and $2 \%$ of the polymer. However, the A4 polymer in each of the four shares did not give an unambiguous answer how much percentage of the polymer was the best. $0.5 \%, 1.0 \%$ and $2.0 \%$ showed slight fluctuations compared to $3.0 \%$ where there were no fluctuations. On this basis, it is not possible to clearly indicate which percentage gives the best results. In order to know the next properties of this polymer, further tests are necessary, mainly strength tests as well as seasoning of samples containing polymers and phase change material all together. To confirm the operation of a mixture of gypsum, polymer and paraffin, real-scale tests under all-year atmospheric conditions seem necessary.

\section{REFERENCES}

1. Lushnikova, N., \& Dvorkin, L. (2016). Sustainability of gypsum products as a construction material. In J. Khatib, ed., Woodhead Publishing Series in Civil and Structural Engineering (pp. 643-681). https://doi.org/https://doi.org/10.1016/B978-008-100370-1.00025-1

2. Cheremisinoff, N. P. (2012). Solid wastes. In Handbook of Pollution Prevention and Cleaner Production (pp. 31-61). https://doi.org/10.1016/b978-1-4377-7815-1.00002-3

3. Felsing, W. A., \& Potter, A. D. (1930). Gypsum and Gypsum Products. Journal of Chemical Education, 7(12), 2788. https://doi.org/10.1021/ed007p2788

4. Mróz, P., \& Mucha, M. (2018). Hydroxyethyl Methyl Cellulose as a Modifier of Gypsum Properties. Journal of Thermal Analysis and Calorimetry, 134(2), 1083-1089. https:// doi.org/10.1007/s10973-018-7238-3

5. Pourchez, J., Peschard, A., Grosseau, P., Guyonnet, R., Guilhot, B., \& Vallée, F. (2006). HPMC and HEMC Influence on Cement Hydration. Cement and Concrete Research, 36(2), 288-294. https://doi.org/10.1016/j.cemconres.2005.08.003

6. Bülichen, D., Kainz, J., \& Plank, J. (2012). Working Mechanism of Methyl Hydroxyethyl Cellulose (MHEC) as Water Retention Agent. Cement and Concrete Research, 42(7), 953-959. https://doi.org/10.1016/j.cemconres.2012.03.016

7. Patural, L., Marchal, P., Govin, A., Grosseau, P., Ruot, B., \& Devès, O. (2011). Cellulose Ethers Influence on Water Retention and Consistency in Cement-Based Mortars. Cement and Concrete Research, 41(1), 46-55. https://doi.org/10.1016/j.cemconres.2010.09.004

8. Heim, D., Mrowiec, A., Pralat, K., \& Mucha, M. (2018). Influence of Tylose MH1000 Content on Gypsum Thermal Conductivity. Journal of Materials in Civil Engineering, 30(3). https://doi.org/10.1061/(ASCE)MT.1943-5533.0002177

9. Almeida, R. F. C., \& Klemm, A. J. (2018). Effect of GGBS on Water Absorption Capacity and Stability of Superabsorbent Polymers Partially Crosslinked with Alkalis. Journal of Materials in Civil Engineering, 30(12), 4018315. https://doi.org/10.1061/(ASCE) MT.1943-5533.0002511

10. Singh, M., \& Garg, M. (1996). Relationship between Mechanical Properties and Porosity of Water-Resistant Gypsum Binder. Cement and Concrete Research, 26(3), 449-456. https://doi.org/10.1016/S0008-8846(96)85032-0

11. Garbalińska, H., Kowalski, S. J., \& Staszak, M. (2013). Moisture Diffusivity in Mortars of Different Water-Cement Ratios and in Narrow Ranges of Air Humidity Changes. International Journal of Heat and Mass Transfer, 56(1-2), 212-222. https://doi. org/10.1016/j.ijheatmasstransfer.2012.09.026 
12. Garbalińska, H., \& Wygocka, A. (2014). Microstructure Modification of Cement Mortars: Effect on Capillarity and Frost-Resistance. Construction and Building Materials, 51, 258-266. https://doi.org/10.1016/j.conbuildmat.2013.10.091

13. Hawes, D. W., Feldman, D., \& Banu, D. (1993). Latent Heat Storage in Building Materials. Energy and Buildings, 20(1), 77-86. https://doi.org/10.1016/0378-7788(93)90040-2

14. Feldman, D., Banu, D., \& Hawes, D. W. (1995). Development and Application of Organic Phase Change Mixtures in Thermal Storage Gypsum Wallboard. Solar Energy Materials and Solar Cells, 36(2), 147-157. https://doi.org/10.1016/0927-0248(94)00168-R

15. Stovall, T. K., \& Tomlinson, J. J. (1995). What are the Potential Benefits of Including Latent Storage in Common Wallboard? Journal of Solar Energy Engineering, 117(4), 318-325. Retrieved from http://dx.doi.org/10.1115/1.2847868

16. Feldman, D., Shapiro, M. M., Banu, D., \& Fuks, C. J. (1989). Fatty Acids and their Mixtures as Phase-Change Materials for Thermal Energy Storage. Solar Energy Materials, 18(3-4), 201-216. https://doi.org/10.1016/0165-1633(89)90054-3

17. Peippo, K., Kauranen, P., \& Lund, P. D. (1991). A Multicomponent PCM Wall Optimized for Passive Solar Heating. Energy and Buildings, 17(4), 259-270. https://doi. org/10.1016/0378-7788(91)90009-R

18. Kośny, J. (2015). Chapter 2: Short history of PCM applications in building envelopes. In PCM-Enhanced Building Components (p. 281). https://doi.org/10.1007/978-3-31914286-9

19. Jurkowska, M., \& Szczygieł, I. (2016). Review on Properties of Microencapsulated Phase Change Materials Slurries (mPCMS). Applied Thermal Engineering, 98, 365-373. https://doi.org/10.1016/j.applthermaleng.2015.12.051

20. Konuklu, Y., Ostry, M., Paksoy, H. O., \& Charvat, P. (2015). Review on Using Microencapsulated Phase Change Materials (PCM) in Building Applications. Energy and Buildings, 106, 134-155. https://doi.org/10.1016/j.enbuild.2015.07.019

21. Li, C., Yu, H., Song, Y., \& Liu, Z. (2019). Novel Hybrid Microencapsulated Phase Change Materials Incorporated Wallboard for Year-Long Year Energy Storage in Buildings. Energy Conversion and Management, 183, 791-802. https://doi.org/10.1016/J. ENCONMAN.2019.01.036

22. Halimov, A., Lauster, M., \& Müller, D. (2019). Validation and Integration of a Latent Heat Storage Model into Building Envelopes of a High-Order Building Model for Modelica Library AixLib. Energy and Buildings, 202, 109336. https://doi.org/10.1016/J. ENBUILD.2019.109336

23. Gowreesunker, B. L., Stankovic, S. B., Tassou, S. A., \& Kyriacou, P. A. (2013). Experimental and Numerical Investigations of the Optical and Thermal Aspects of a PCM-Glazed Unit. Energy and Buildings, 61, 239-249. https://doi.org/10.1016/j. enbuild.2013.02.032

24. Oliver, A. (2012, May 1). Thermal Characterization of Gypsum Boards with PCM Included: Thermal Energy Storage in Buildings through Latent Heat. Energy and Buildings, 48, 1-7. https://doi.org/10.1016/j.enbuild.2012.01.026

25. Wang, X., Yu, H., Li, L., \& Zhao, M. (2016). Research on Temperature Dependent Effective Thermal Conductivity of Composite-Phase Change Materials (PCMs) Wall Based on Steady-State Method in a Thermal Chamber. Energy and Buildings, 126, 408414. https://doi.org/10.1016/j.enbuild.2016.05.058 


\title{
INDIVIDUĀLU POLIMĒRU PĀRVEIDOTĀ SINTĒTISKĀ G̣IPŠA SAVIENOJUMU PARAFINA CAURLAIDĪBA
}

\author{
K. Povala, D. Heims \\ Kopsavilkums
}

Rakstā aprakstīti piecu dažādu ǵipša kompozītu eksperimentālie pētījumi, ņemot vērā parafīna caurlaidību. Kompozīti izgatavoti no sintētiska ğipša, parafīna un polimēriem. Paraugi tika izgatavoti no ǵipša suspensijas, kas sastāv no viegli sajaucamām sastāvdaḷām šķidrā stāvoklī. Pēc 7 dienu nogatavināšanas tika novērtēts paraugu stāvoklis un noteikts žāvēšanas laiks. Pêtījumā otrajā daḷā tika analizēta dažādu paraugu necaurlaidība. Rezultāti liecina, ka pēc trīs nedēḷu testiem paraugam A4 bija lielāka necaurlaidība. Citiem polimēriem raksturīga zemāka necaurlaidība. Polimēru saturs ietekmē arī galīgos rezultātus, tomēr tieša saistība starp polimēra saturu un parafīna necaurlaidību netika novērota.

02.10.2019. 